Dr. sc. Bosiljka Britvić Vetma, izvanredna profesorica

Pravni fakultet Sveučilišta u Splitu

Dr. sc. Marko Turudić, docent

Pravni fakultet Sveučilišta u Zagrebu

\title{
ULOGA STRANKE U UPRAVNOM DJELOVANJU JAVNOPRAVNIH TIJELA
}

\author{
UDK: 342.9 \\ Primljeno: 1. rujna 20185 \\ Izvorni znanstveni rad
}

\begin{abstract}
Autori u predmetnom članku razmatraju ulogu, a samim time i položaj stranke u upravnom djelovanju javnopravnih tijela. Pritom poseban naglasak stavljaju na načelu dobre uprave. Ističu kako je promicanje dobre uprave usko povezano s demokratizacijom uprave usmjerenoj prema zagovaranju razvoja koji kreće od građanina podređenog upravi prema građaninu ravnopravnom upravi. U tu svrhu autori razmatraju i utjecaj europskog prava na zaštitu prava stranke.
\end{abstract}

Ključne riječi: stranka, zaštita prava, dobra uprava

\section{UVOD}

U klasičnom smislu, upravno pravo ima dvostruku funkciju. Prije svega regulira odnos između građana i države, te odnos između javnopravnih tijela. Ova funkcija je svojstvena i upravnom pravu (pravnim pravilima) koje se primjenjuje na javnopravna tijela u u europskom upravnom prostoru. Ipak, u povijesnom smislu, za razliku od nacionalnih iskustava, naglasak je primarno bio na odnosima između javnopravnih tijela, pa se tek postupno, s produbljivanjem europske integracije, najvažnijim pokazalo to da uprava poštuje prava i slobode pojedinaca, posebice kroz kontrolu zakonitosti. Promicanje načela dobre uprave dovelo je do ponovnog aktualiziranja te regulatorne funkcije kroz njezino obogaćivanje zahtjevnim standardima.

Razmatrajući ulogu stranke u upravnom djelovanju javnopravnih tijela u prvom redu kao „praktični koncept“, važno je utvrditi nužne elemente, koji nisu samo formalni, nego i materijalni, a oko kojih bi se mogao postići određeni konsenzus.

Naime, kako bi stranka bila u mogućnosti zaštititi svoja prava, prethodno moraju biti ispunjeni određeni zahtjevi: 1. zahtjev za dostupnošću domaćeg (nacionalnog) prava, 2. zahtjev za preciznošću domaće pravne norme, te 3 . dostupnost konvencijskog prava. Naime, Europski je sud odredio da zbog načela pravne izvjesnosti moraju biti zadovoljena dva zahtjeva koja proizlaze iz izraza „propisanih zakonom“. Prvo, zakon mora biti dostupan svima na odgovarajući način: građaninu mora biti omogućeno saznanje o značenju odnosno o sadržaju 
pravnog pravila koje će se u određenim okolnostima primijeniti na konkretni slučaj. Drugo, norma se ne može smatrati ,zakonom“ sve dok nije formulirana dovoljno precizno da građaninu omogući da prema njoj uskladi svoje ponašanje: njemu se mora omogućiti - po potrebi, uz odgovarajući savjet - da predvidi, do stupnja koji je razuman u danim okolnostima, posljedice koje njegovo ponašanje može uzrokovati. Držimo neospornim da adresati pravne norme ne mogu stvarno i konkretno znati svoja prava i obveze te predvidjeti posljedice svojega ponašanja ako pravna norma nije dovoljno određena i precizna. Neosporno je da su pravne norme nužne, ali i granice onoga što uprave smiju. ${ }^{1}$

U tom smislu pojedinci imaju pravo na dobru upravu. Načelo dobre uprave podrazumijeva da se pojedinac snažnije uzima u obzir. Ne radi se samo o tome da mu se zajamče postupovna upravna prava, već i o tome da mu se osigura mjesto $\mathrm{u}$ funkcioniranju uprave. Naime, promicanje dobre uprave usko je povezano s demokratizacijom uprave usmjerenoj prema zagovaranju razvoja koji kreće od građanina podređenog upravi prema građaninu ravnopravnom upravi. Dobra uprava također pridonosi učvršćivanju mjesta pojedinca u europskom upravnom prostoru.

Postupnim ustanovljavanjem europskog upravnog prostora također se obnavljaju odnosi između uprava različitih pravnih poredaka. Nastanak složene uprave utječe na tradicionalne modele obavljanja njihovih zadaća i kontrole njihova djelovanja. Prije svega, uprave podliježu obvezama koje potječu iz drugačijeg pravnog poretka. $\mathrm{K}$ tome, njihova odlučujuća uloga u vršenju prava Unije podrazumijeva izgradnju održivih odnosa među njima. Produbljivanje europskog upravnog prostora uzrokuje bliske kontakte i suradnju među upravama. Uprave, koje tradicionalno funkcioniraju na temelju endogenih čimbenika, također se razvijaju kroz svoju organizaciju i svoje djelovanje. U okviru promicanja dobrog upravljanja, razvoj dobre uprave usmjeren je na potvrđivanje opsega načela odane suradnje u upravnom području. Naime, promicanje upravne suradnje neophodno je kako bi se osigurala učinkovita provedba prava Unije.

\section{UČVRŠĆIVANJE POLOŽAJA POJEDINCA}

Razvoj upravnog djelovanja omogućuje da se pojedinca sve snažnije uzima u obzir u okviru upravnog procesa. Naime, uprava daje prednost određenoj subjektivizaciji odnosa između uprave i građana, koja je usmjerena prema uspostavljanju ravnopravnijeg upravnog odnosa. Prema riječima Gillesa Dumonta, „upravna demokracija je značajno povezana s promicanjem smanjenja nejednakosti u odnosima između uprave i građana i s razvojem sudjelovanja“.2. Jednako tako se pravo na dobru upravu uključuje u proces upravne demokracije i tada označava nastanak novog statusa pojedinca u njegovim odnosima s upravom.

1 Vidi odluku Ustavnog suda broj: U-I-659/1994 i dr. od 11. listopada 2000.

2 Dumont, G., La citoyenneté administrative, doktorska disertacija, Sveučilište Panthéon-Assas (Paris 2), 2002., str. 576. 
Kapacitet prava na dobru upravu u uspostavljanju takvog procesa ipak još nije do kraja jasan. Naime, takav ekstenzivni koncept nije se još konkretizirao u pravnom poretku Unije. Trenutni razvoj usmjeren je na relativiziranje isključivog doprinosa dobre uprave produbljenju prerogativa priznatih pojedincima u upravnim odnosima.

Istovremeno Europska konvencija za zaštitu ljudskih prava, ${ }^{3}$ Povelja Europske unije o temeljnim pravima, ${ }^{4}$ kao i Zakon o općem upravnom postupku Republike Hrvatske ${ }^{5}$ jamče obilje međusobno prožimajućih individualnih prava. Tako Zakon o općem upravnom postupku sadrži stanoviti broj načela upravnoga postupka te drugih odredaba kojima je osnažen, odnosno poboljšan položaj stranke u upravnom postupku. To se prije svega odnosi na načelo razmjernosti u zaštiti prava stranaka i javnog interesa. ${ }^{6}$ Zahtjeve i potrebe vremena slijedi i načelo pristupa podacima i zaštite podataka. ${ }^{7}$ Zakon o općem upravnom postupku sadrži i načelo Prava stranke na pravni lijek. ${ }^{8}$ U Zakonu o općem upravnom postupku sadržano je i načelo zaštite stečenih prava stranke. ${ }^{9}$ Nadalje, što se pravnog položaja stranke u upravnom postupku tiče, uz upravo navedene zakonske odredbe u kojima je određen procesni položaj stranke, potrebno je ukazati na odredbe članka 30. i 52. Zakona o općem upravnom postupku. Prvospomenutim člankom određeno je da se stranci u postupku mora omogućiti izjašanjavanje o svim činjenicama, okolnostima i pravnim pitanjima važnima za rješavanje upravne stvari. Prema članku 52., pravo je stranke sudjelovati u ispitnom postupku sve do donošenja odluke u upravnoj stvari tako da daje izjave i objašnjenja, iznosi činjenice i okolnosti koje su bitne za rješavanje upravne stvari te pobija točnost navoda koji se ne slažu s njezinim navodima. S druge pak strane, službena je osoba dužna omogućiti stranci izjašnjavanje o svim okolnostima i činjenicama iznesenima u ispitnom postupku, prijedlozima za izvođenje dokaza i podnesenim dokazima, sudjelovanje u izvođenju dokaza, postavljanje pitanja drugim strankama, svjedocima i vještacima preko službenih osoba a uz njezino dopuštenje i neposredno te upoznavanje s rezultatima izvođenja dokaza i izjašanjavanje o tim rezultatima. Istodobno, stranka ima dužnost sudjelovati u utvrđivanju činjenica važnih za rješavanje u upravnoj stvari, kao i osobno dati izjavu kada to zatraži službena osoba ili kada je to propisano zakonom. Za rješavanje upravnih predmeta i zaštitu prava i interesa stranaka posebno je važno stajalište Ustavnoga suda Republike Hrvatske iskazano u odluci iz 2010. godine. Prema tom stajalištu, ,pravila i sredstva dokazivanja čine dio cjeline postupovnih pravila upravnog postupka, sadržanih u Zakonu o općem upravnom postupku i kao takva neodvojiva su sastavnica postupovnih jamstava pravičnog suđenja, zaštićenih Ustavom. Ustavni sud štiti ustavno jamstvo pravičnog suđenja (odlučivanja)

\footnotetext{
3 Narodne novine, međunarodni ugovori, Narodne novine 18/99, 6/99, 14/02, 13/03, 9/05, 1/06, 2/10.

4 Službeni list Europske unije, 2007/C 303/01.

5 Narodne novine, 47/09.

6 Zakon o općem upravnom postupku, članak 6.

7 Zakon o općem upravnom postupku, članak 11

8 Zakon o općem upravnom postupku, članak 12.

9 Zakon o općem upravnom postupku, članak 13.
} 
ispitujući eventualno postojanje postupovnih povreda u postupcima pred sudovima i drugim državnim tijelima, odnosno tijelima koje imaju javne ovlasti. Pružajući tu zaštitu, Ustavni sud sagledava cjelokupni postupak kao jedinstvenu cjelinu te ocjenjuje je li on bio vođen na način koji podnositelju osigurava pravično suđenje (odlučivanje), odnosno je li tijekom postupka počinjena povreda takvog značenja da postupak kao cjelinu čini nepravičnim za podnositelja. Sagledavajući konkretan slučaj s tog stajališta, Ustavni sud primjećuje da je postupanje nadležnih upravnih tijela i Upravnog suda, utvrđeno u konkretnom slučaju (neosnovano ograničenje dokaznih sredstava, odnosno mogućnosti utvrđivanja relevantnih činjenica u skladu s načelom materijalne istine, uz bitne nedostatke u obrazlaganju zauzetih stajališta), dovelo do povrede podnositeljeva ustavnog prava na pravično suđenje (odlučivanje) s aspekta općih jamstava sadržanih u članku 29. stavak 1. Ustava, koja jamstva moraju biti poštovana i u postupku sudske kontrole zakonitosti pojedinačnih akata uprave iz članka 19. stavka 2. Ustava. ${ }^{" 10}$

\section{DOBRA UPRAVA I PROMICANJE UPRAVNIH PRAVA GRAĐANA}

Uključivanje dobre uprave u Povelju Europske unije o temeljnim pravima pokazuje izričitu vezu između dobre uprave i upravnih prava građana.

\subsection{Jasna poveznica između upravnih prava građana i dobre uprave}

Peta glava Povelje Europske unije o temeljnim pravima nastoji obogatiti koncept građanstva Unije, time što tim pravima pridodaje nova prava iz upravnog područja. Dakle, upravna prava građana razlikuju se od klasičnih prava građana Unije, posebice zbog proširene definicije nositelja tih prava.

\subsubsection{Inovativan razvoj građanstva u upravnom području}

Člankom 8. Ugovora iz Maastrichta ${ }^{11}$ uvodi se građanstvo Unije kojim se teži „spojiti nova i već postojeća prava koja su državljani zemalja članica stekli i koja se odnose na izgradnju Zajednice. Kao rezultat ove izgradnje, njegova je uloga ponovno dinamiziranje Zajednice" ${ }^{12}$ Pozivanje na ovaj koncept još jednom dokazuje specifičnost europske izgradnje, a naročito u odnosu na međunarodno pravo. Naime, pravni poredak Unije stvara prava, ne samo u korist države, već i u korist privatnih

10 Odluka Ustavnog suda RH, broj:U-III-1001/2007. od 7. srpnja 2010.

Više o svemu vidi u Ljubanović, B., Petrović, I., „Stranka u Hrvatskom upravnom postupku i upravnom sporu“, Pravni vjesnik: časopis za pravne i društvene znanosti Pravnog fakulteta Sveučilišta J.J. Strossmayera u Osijeku, Vol. 31 No. 1, Osijek, 2015., str. 127-140.

11 Današnji članak 20. Ugovora o funkcioniranju Europske unije.

12 Weiller, J., Les droits des citoyens européens, RMUE, 1996., str. 35. 
osoba. Pravni poredak se osobito uključuje u volju približavanja naroda europskoj izgradnji, pa prema tome i u osnaživanje legitimnosti Europske unije. Građanstvo ima društveno-političku dimenziju i treba omogućiti razvoj osjećaja pripadnosti zajednici. Temeljeći se na tom pristupu, možemo ga odvojiti od ideje države nacije i uključiti u europski projekt.

Kada se radi o građanstvu Unije, teško mu je odrediti konkretni sadržaj koji ne može biti samo simbolički. Jasno, prava se povezuju s građanstvom, međutim, ona još nemaju stvarnu političku dimenziju. Sud Europske unije također je pribjegavao konceptu građanstva pri promicanju načela nediskriminacije. Građanstvo Unije osmišljeno je na način da predstavlja sredstvo kojim se osigurava poštovanje prava koja proizlaze iz pravnog poretka Unije. Istina je također da europsko građanstvo nema svoja bitna svojstva, a činjenica je da ,građani imaju ovlast, odlukom većine, proglasiti obvezna pravila i usmjeriti društveno-gospodarsku strukturu države. (...) Ako želimo odrediti koja su bitna prava građanstva, treba istražiti sve instrumente i mehanizme koji građanima omogućuju kontrolu države i njezinih tijela“. ${ }^{13}$

U ovoj perspektivi, promicanje njezine upravne dimenzije može izgledati poput načina na koji će se obogatiti građanstvo Unije. Poveljom Europske unije o temeljnim pravima, umetanje članka $41 .{ }^{14}$ na temu građanskih prava u Glavu V. obilježava volju prezidija (radnog predsjedništva) da naglasi specifičan doprinos prava na dobru upravu, što nije samo dodatak pravu na pravedno suđenje. Njegov je doseg veći jer ,radi se o odlučujućem doprinosu nastanku upravnih prava građana, nužno povezanih s pravnom državom, budući da je europskim upravnim sustavima, kao i ostalim pluralističkim demokracijama, zajedničko to da imaju upravu koja podliježe pravu“ “. ${ }^{15}$ Ipak, uključivanje dobre uprave u Glavu V. o pravima građana moglo je biti predmet kritike. Naime, neki smatraju da se „značajka članka 41. prilično jasno razlikuje od ostalih prava iz Povelje koji se nalaze u poglavlju „građanska prava“ kao što je to u Ugovoru iz Maastrichta iako se ne ograničavaju samo na građane (članci 42. do 44.). Naime, dok se bitna funkcija tih potonjih prava sastoji od demokratske kontrole javnih vlasti, članak 41. u bitnome obuhvaća zaštitu pojedinca u odnosu na upravu. "“16 Interes uvođenja koncepta upravnih prava građana na razini Europske unije temelji se više na njihovoj evokacijskoj snazi nego na njihovim izravnim posljedicama, poput europskog građanstva. Ovdje

13 Ibid.

14 ,1. Svatko ima pravo da institucije, tijela, uredi i agencije Unije njegove predmete obrađuju nepristrano, pravično i u razumnom roku. 2. To pravo uključuje: pravo svake osobe na saslušanje prije poduzimanja bilo kakve pojedinačne mjere koja bi na nju mogla nepovoljno utjecati; pravo svake osobe na pristup svojem spisu, uz poštovanje zakonitih interesa povjerljivosti te profesionalne i poslovne tajne; obvezu uprave da obrazloži svoje odluke. 3. Svaka osoba ima pravo da Unija nadoknadi štetu koju njezine institucije ili službenici prouzroče pri obavljanju svojih dužnosti, u skladu s općim načelima koja su zajednička pravima država članica. 4. Svaka se osoba može pisanim putem obratiti institucijama Unije na jednom od jezika Ugovora i mora dobiti odgovor na istom jeziku.“

15 Ziller, J., „Les administrations doivent faire face à l'élargissement et à l'approfondissement de l'intégration européenne - avec ou sans traité constitutionnel“, RFAP, 114/05, 2005., str. 213.

16 Ladenburger, C., L'apport de la Charte dans le domaine des droits civil et politiques, Bruxelles, Bruyent, 2002., str. 105. 
postoji evidentno odstupanje između sadržaja prava na dobru upravu sadržanog u članku 41. Povelje i njegove potencijalne povezanosti s građanstvom. Ekstenzivna definicija njegovih nositelja doprinosi utjecaju na suvislost koncepta.

\subsubsection{Ekstenzivna definicija nositelja upravnih prava građana}

Izričaj članka 41. Povelje Europske unije o temeljnim pravima podrazumijeva široku definiciju svojih nositelja, a potvrđuje da područje upravnih prava građana nadilazi područje državljanstva. Referiranje na „građanstvo“ a ne na „prava građana" vjerojatno omogućuje širi pristup nositelja, što se u konačnici očituje u „građanstvu u formi koncentričnih krugova““ ${ }^{17}$ „Prvi, uži krug utječe na državljanina države članice koji živi u državi članici, a odnosi se na samo političko pravo u strogom smislu te riječi kako je sadržano u Povelji. Drugi krug obuhvaća građanina u strogom smislu i utječe na prava kretanja i pomoći. Treći krug koristi građaninu ili stanovniku, a odnosi se na neka prava političke naravi koja su povezana s demokratskim načelom, ali se odnosi i na dozvolu za kretanje državljana trećih zemalja. I konačno, tek četvrti krug odnosi se na ljudsko biće i na temeljno pravo na zaštitu protiv samovolje“. ${ }^{18}$ Jednako tako, potencijalni nositelji upravnih građanskih prava u nastajanju su brojniji nego potencijalni nositelji građanstva Unije koje je ograničeno na državljane država članica. Radi se o mnogo širem pojmu koji poziva na relativiziranje kriterija državljanstva.

Međutim, formulacije sadržane u Povelji sadrže dvosmislenosti. Prava iz članka 41. kao i iz članka 42. ima svaka fizička ili pravna osoba s boravištem u Uniji. ${ }^{19}$ Tekst ovog područja primjene ima za posljedicu ograničavanje građanstva u skladu s teritorijem. K tome, odstupanje između područja primjene članaka 41. i 42. i ostalih članaka iz te glave koja se odnosi na građanstvo omogućuje „razlikovanje prava koja se odnose na političko građanstvo, namijenjeno samo europskim građanima, od onih koja se odnose na upravno građanstvo čija je primjena šira, kao što je i primjena društvenog građanstva, a koja se mogu povezati s pravima iz Glave IV. „Solidarnost“. ${ }^{20}$ Ova razlika između adresata može se također objasniti naravnom razlikom među pravima. Naime, pravo na dobru upravu je ,sastavnica načela zaštite protiv proizvoljnog“, dok je pravo na pristup dokumentima „,bitni dio načela transparentnosti uprave".$^{21}$ Upravo zato, prema Povelji, svaki pojedinac ima pravo na dobru upravu zbog njezina temeljnog obilježja. Takva koncepcija osnažuje čuđenje u pogledu njezina uključivanja u poglavlje o građanstvu. Osim toga, postoji odstupanje u području primjene između ugovora (pravo na uporabu vlastitog jezika)

17 Fallon, M., Les droits fondamentaux liés à citoyenneté de l'Union européenne, sous les regard croisés du traité C.E. et de la Charte, Bruxelles, Bruyent, 2002, str. 160.

18 Ibid.

19 Ibid.

20 Ziller, J., op. cit.

21 Fallon, M., op. cit. str. 155. 
i članka 41. Povelje. Ove varijacije mogu izazvati nekoherentnosti, dok bi prava koja se odnose na građanstvo imala nositelje „promjenjive geometrije“. ${ }^{22}$

Izrada Povelje generira neizvjesnosti u pogledu nastanka koncepta građanstva, a potvrđuje ih i priznanje prava na dobru upravu. Istina, ne treba zanemariti razvojni kapacitet koncepta građanstva Unije, no, žalosno je što simbolika nije prevagnula nad pravnom snagom. Budući da se ne može smatrati pravim subjektivnim pravom, uključivanje prava na dobru upravu u područje građanstva u današnje vrijeme pokazuje se vrlo simboličkim i može utjecati na potencijal koncepta upravnih prava građana za projekt europske integracije.

\subsection{Ograničeni doseg izgradnje upravnih građanskih prava na temeljima dobre uprave}

Promicanje dobre uprave doprinosi uzimanju u obzir pojedinca u njegovim odnosima s upravom. Njezina evocirajuća snaga nastoji pridonijeti zbližavanju, pa makar i simboličkom, između uprave Unije i pojedinca. Ono odražava razvoj upravnih odnosa. Kao izvor izravne povezanosti s Europskom unijom, upravna prava građana sudjeluju u njezinoj demokratizaciji. Ipak, promicanje dobre uprave ne može biti temelj za taj cijeli postupak.

\subsubsection{Razvoj upravnih odnosa}

Koncept upravnih prava građana razvio se u unutarnjem poretku i on predstavlja završetak razvoja položaja što ga ima građanin. U prvo vrijeme, građanina se uzimalo kao ,pokorenog kojem valja nametati, u svom vlastitom interesu, potrebne stegovne mjere. Ne tolerirajući bilo kakvu raspravu, koja je u svojoj biti nepojmljiva i neprihvatljiva, uprava uvijek nastoji smjestiti građanina pod svoju vlast, pokoriti ga svojim zahtjevima, pa makar pod izlikom pružanja usluga...".23 Položaj građanina postupno se promijenio, posebice zahvaljujući njegovu položaju korisnika. U biti, on više nije pokoren jer postaje korisnik usluga koje pruža uprava. Konačno, doprinos u liku građanina u upravnom funkcioniranju za posljedicu ima priznanje prerogativa u korist građanina, poput prava na uvid i prava na sudjelovanje. ${ }^{24}$ Prema tome, izgradnja upravnih prava građana usmjerena je prema obnavljanju odnosa između uprave i pojedinca.

Promicanje dobre uprave dovelo je do ponovne uspostave ravnoteže u odnosima s upravom, odnosno uzimanje u obzir pojedinaca koji više nisu predmeti već subjekti sukladno pravu. Ono pridonosi izgradnji temelja za dijalog. U tradicionalnom smislu, „isključivo referiranje na pravilo i strogu primjenu zakonskih tekstova omogućuju

22 Simon, D., Les droits du citoyen de l'Union, RUDH, Paris, 2002., str. 22.

23 Chevallier, J., Science administrative, Paris, PUF, 2007., str. 349.

24 Ibid. 
izbjegavanje svake osobne i individualizirane rasprave“. ${ }^{25}$ Suprotno tome, dobra uprava pridonosi pojačanoj humanizaciji odnosa između pojedinaca i uprave koja za posljedicu ima određeno popuštanje u primjeni zakona, posebice kroz porast broja neformalnih kontakata. Dijalog treba uspostaviti u skladu s očekivanjima građanina. Zahtjevi su u tom smislu mnogobrojni: dijalog, pristojnost, poštovanje. Pojam dobre uprave nastoji pružiti odgovor na te zahtjeve. Dobra uprava omogućuje pojedincima da ih uprava na određeni način uzme u obzir kada, primjerice, ona treba ispuniti njihove početne zahtjeve, čak i u obliku telefaksa, ali i njihove zahtjeve koje podnose o informacijama koji se odnose na njihov položaj. Prema riječima nezavisnog odvjetnika Albera, načelo dobre uprave zahtijeva da tijela vlasti odgovaraju na dopise koji su im upućeni. (...) Neljubazni izostanak odgovora na dopis zasigurno zaslužuje kritiku. ${ }^{26}$ Prema tome, kršenje ove obveze ne može predstavljati kršenje bitne formalnosti koja se temelji na poništenju akta. Pa ipak, to je u interesu dobre uprave jer ona potiče upravu na promjenu svog postupanja prema pojedincima.

Dobra je uprava također podupirala veću personalizaciju u odnosima između uprave i građana. Uprava treba prilagoditi svoje držanje u skladu s karakteristikama svog sugovornika. Na primjer, treba osigurati tumačenje kako bi se svim kandidatima na natječaju omogućilo da rabe svoj materinski jezik. Sudska praksa koja se odnosi na rokove također odražava volju da se individualna stanja uzimaju u obzir. Upravna tijela vlasti ne mogu raspolagati svojim prerogativima onako kako žele kada se radi o vremenskoj perspektivi. Razvoj novih tehnologija također je doprinio većoj dostupnosti usluga koje pruža uprava. Provedba načela dobre uprave utječe na tradicionalnu predodžbu o birokratskoj i nedostupnoj upravi koja drži građane na udaljenosti i koju odlikuje krutost pri ostvarivanju kontakata.

Osim toga, koncept građanstva odnosi se na pitanje nametnutih zadaća. Naime, ako status građanina omogućuje pojedincu da postane čimbenik u upravnom procesu, tada ga on, u određenoj mjeri i obvezuje da bude aktivan. Ovaj je aspekt vrlo razvijen u belgijskoj doktrini o temeljima dobre uprave. Prema tome, odnos građanstva dvosmjerni je i uzajamni odnos između uprave i građanina. Neke presude upućuju na nekoliko znakova te promjene. U presudi Dieter Strack, Sud ističe obvezu koju pojedinci trebaju ispuniti kao dokaz o svom učinkovitom i brižnom postupanju. Također, podnositelj zahtjeva, odnosno tužitelj ne može prigovarati zbog rokova koje nalaže upravno tijelo vlasti zato što se on sam nije na vrijeme pobrinuo da ih ispoštuje. ${ }^{27}$ Nezavisni odvjetnik Ruiz-Jarabo Colomer također je razvio ovaj aspekt tako što se referirao na belgijski pristup. On kaže da ,ako se radi o tužbi zbog općeg načela dobre uprave, sjećam se presude (belgijskog) Državnog savjeta koji je točno rekao da 'zahtjevi u pogledu dobre uprave također vrijede za građanina. Ne možemo zahtijevati od uprave da pokazuje izvanredan zanos u obrani prava onog tko nije rabio redovna sredstva kojima je raspolagao u takvoj obrani' “. ${ }^{28}$ Ovaj

\footnotetext{
25 Ibid.

26 Ibid.

27 Sud Europske unije, 27. studenoga 1986., Dieter Strack / Europski parlament.

28 Schockweiler, F., Le prétendu déficit démocratique, JTDE, Paris, 1994., str. 25.
} 
koncept potvrđuje doprinos uprave u ponovnoj uspostavi ravnoteže u odnosima s upravom, koji ipak ne treba dovesti do nadmoći pojedinca nad upravom. Taj koncept predstavlja klasičnu primjenu dobre uprave koja teži očuvanju učinkovitosti uprave.

Promicanje načela dobre uprave doprinosi učvršćivanju položaja pojedinca u upravnom procesu Europske unije. Međutim, ipak ostaje ograničen njegov doprinos produbljivanju upravne demokracije koju uvodi koncept građanstva.

\subsubsection{Doprinos dobre uprave procesu demokratizacije uprave}

Ponavlja se isticanje deficita legitimnosti Unije. Učinkovitost izvršnosti prava Unije nije dostatna za osiguravanje legitimnosti Unije. U većini pretpostavki, ova je kritika usko povezana ili izjednačena s njezinim demokratskim deficitom. To se odnosi na ideju prema kojoj se može kritizirati „činjenica da normativne akte, koji se u državama članicama nalaze u zakonodavnoj nadležnosti parlamenata, usvajaju na razini zajednice vlade država članica, a da Europski parlament nema ovlasti u odlučivanju“ “. ${ }^{29}$ Naime, iako europski parlament postupno zadobiva sredstva uz pomoć kojih se afirmira u sklopu postupka donošenja odluka, demokratizacija Europske unije i dalje se nalazi na vrhu prioriteta programa Europske unije. Zasigurno je produbljenje procesa europske integracije uključivalo uzimanje u obzir demokratskih zahtjeva. ${ }^{30}$ Usvajanje Ugovora o funkcioniranju Europske unije doprinijelo je ublažavanju propusta kroz jačanje položaja europskog parlamenta. Ipak i dalje ostaje taj osjećaj, iako je istina da ta tvrdnja može istaknuti razlike. Upravo se zato moglo razmišljati o razvoju drugih oblika uključivanja građana, osim kroz izbore. Bijela knjiga o upravljanju potvrdila je postojanje sumnji pojedinaca u pogledu svrhe postojanja Europske unije. Tako se čini da je građanima teško zamisliti da dijele zajedničku sudbinu. Prema tome, neophodno je da ih se u što većem broju uključi u određivanje i vođenje politika Unije. S obzirom na neprikladnost i iscrpljenost tradicionalnog modela, promicanje demokratizacije uprave ponavlja se u državama članicama. Uvode se mehanizmi s ciljem povećanja sudjelovanja građana, iako je jasno da se pitanje demokratskog deficita ne može procijeniti niti riješiti referiranjem na klasični parlamentarni model. ${ }^{31}$

Poveznicu između načela dobre uprave i demokratizacije mogao je istaknuti europski ombudsman, iako je potrebno razlikovati te pojmove. Dobra uprava doprinosi upravnoj demokraciji jer obogaćuje proceduralnu demokraciju kojom se uređuju postupci koji omogućuju djelovanje pojedinaca. Upravna proceduralna demokracija ne predstavlja minoran oblik u odnosu na političku demokraciju. Proceduralno oblikovanje uprave omogućuje da je građani kontroliraju, što osnažuje odgovornost uprave koja predstavlja pojam u središtu demokratskog procesa. Naime, prema riječima Dominique Custos, ,idealna upravna demokracija obuhvaća

29 Ibid.

30 Pescatore, P., Les exigences de la démocratie et la légitimité de la Communauté européenne, Bruxelles, Bruylant, 2008., str. 465.

31 Ibid. 
tri dimenzije: ona uključuje pravo na znanje (...), ona također obuhvaća pravo da se građane sasluša (...) i konačno uključuje pravo na uvid“. ${ }^{32}$ Prema tome, upravna demokracija uključuje priznanje prava na informacije i na sudjelovanje u korist pojedinaca što istovremeno jača njihovu sposobnost kontrole upravnog djelovanja.

Dobra uprava također doprinosi jačanju zahtjeva u smislu accountabilityja. Koncept „accountability“, koji se može prevesti pojmom „odgovornosti“, podrazumijeva da tijela javne vlasti moraju podnijeti račune o svom djelovanju i svojim odlukama javnosti, te se trebaju podvrgnuti svakom ispitivanju u skladu s njihovom službom. Završetak procesa odgovornosti može biti kazna u onoj mjeri u kojoj tijelo javne vlasti nije ispunilo svoje zadaće. Ovaj mehanizam prati različite modalitete, a uključuje čak i upravnosudsku kontrolu. Zahtjev u pogledu odgovornosti ojačan je u okviru Europske unije, a radi se o jednom od načela sadržanih u Bijeloj knjizi o europskom upravljanju. Jačanje kontrole otvorenije uprave čini se kao način na koji bi se, barem djelomično, moglo ispraviti nedostatke predstavničkog sustava Unije. Produbljivanje upravne demokracije tako bi se moglo shvatiti kao polovično rješenje za slabost predstavničke demokracije.

Ako se dobra uprava odražava u diskursu sklonom promicanju demokratskih procesa u funkcioniranju uprave, ona ne omogućuje da se istinski utemelji pravo na sudjelovanje pojedinaca pri usvajanju mjera općeg opsega. Takvo se rješenje primijenilo prilikom ispitivanja antidampinških postupaka. U predmetu Fost Plus, sudac Suda Europske unije trebao je ispitati prava koja su priznata zainteresiranim poduzećima posebice pod pretpostavkom šutnje izvedenog prava. Sudac smatra da „u tom slučaju, osporavani akt općeg opsega i obveza dobre uprave, na koju se poziva, predstavlja opće pravno načelo. Na temelju ranije spomenute sudske prakse, ovo načelo ne zahtijeva sudjelovanje osoba na koje ono utječe, tijekom izrade takvog akta. Prema tome, ako nedostaje izričita odredba zakonodavca, tužiteljica ne može iz načela dobre uprave deducirati proceduralno pravo koje bi moglo dovesti do prava na tužbu za poništenje. “33 Organiziranje sudjelovanja pojedinaca u usvajanju upravnih odluka ostaje u početnoj fazi. Naime, ono ovisi o potrebama uprave, posebice u pogledu informacija, a približava se, u tom smislu, pravu da osoba bude saslušana.

Ako Povelja uspostavlja izričitu vezu između dobre uprave i građanstva, tada priznanje postaje čisto formalno. Pojam dobre uprave ne može predstavljati temelj općeg postupka demokratizacije Unije. Naime, dobra uprava odnosi se uglavnom na pojedinačne odnose s upravom. Dok, naprotiv, postupak upravne demokratizacije ima kolektivnu dimenziju koja označava oslanjanje na različite podloge kako bi se produbila.

32 Custos, D., La démocratie administrative au sein de L'Union européenne, Presses universitaires de Caen, Caen, 1996., str. 101.

33 Offerlé, M., Lobbyistes et lobbying de l'Union européenne, PUS, Strassbourg, 2005., str. 327. 


\section{RAZVOJ PREROGATIVA POJEDINCA NA TEMELJIMA KOJI SE RAZLIKUJU OD DOBRE UPRAVE}

Prava na informacije i na sudjelovanje u upravnom procesu predmet su postupnog priznanja u pravnom poretku Unije. Prvo su na temelju transparentnosti razvijeni pojedinačni prerogativi. Ratifikacija Aarhuške konvencije dovela je do produbljivanja određenih proceduralnih upravnih prava.

\subsection{Razvoj prava pojedinaca na temelju transparentnosti}

Poput nacionalnih pravnih poredaka, pravni poredak Unije uzima sve više u obzir imperativ transparentnosti što je vidljivo od stupanja na snagu Ugovora iz Amsterdama. Njegov razvoj doveo je do priznanja prava na pristup dokumentima što je konkretizirano u sekundarnom zakonodavstvu.

\subsubsection{Priznanje prava na pristup dokumentima}

Kraj 90-tih godina prošlog stoljeća obilježio je u pravu Unije početak pokreta definiranja jamstava koja se pružaju pojedincima na temelju transparentnosti. Ova tema doživjela je značajan uspjeh u Europskoj uniji, a dio je okvira šireg od samog upravnog djelovanja. Naime, načelo transparentnosti zauzelo je temeljno mjesto u pravnom poretku Europske unije od samog njegovog uvođenja u Ugovoru iz Amsterdama. Ono predstavlja novu paradigmu za upravu koja je pronašla tumačenje u priznanju prava na pristup dokumentima. Nakon usvajanja Ugovora iz Maastrichta, institucije Unije, koje podržavaju države članice, započele su opće razmatranje o utvrđivanju načela politike pristupa svojim dokumentima. Umetanje novog članka 255. (koji je postao 15. članak Ugovora o funkcioniranju Europske unije) u Ugovoru iz Amsterdama podigao je pravo na pristup dokumentima na razinu primarnog prava, a istovremeno je pružio pravni temelj za usvajanje zakonodavstva. Uvođenje članka 42. u Povelju Europske unije o temeljnim pravima obilježava završetak postupka konstitucionalizacije prava na pristup dokumentima. ${ }^{34}$

Priznanje prava na pristup dokumentima doprinosi jačanju transparentnosti u postupku odlučivanja Unije koji je osmišljen kao jedan od načina na koji se nastoji nadoknaditi demokratski deficit. Njegov razvoj predstavlja bitan element upravne transparentnosti i demokracije. Naime, informiranje pojedinaca predstavlja primarni aspekt kontrole koja se može vršiti nad upravom. Priznanje prava na pristup usmjereno je na jačanje pristupa javnosti informacijama kojima raspolažu institucije. Pravo na pristup informacijama tradicionalno ispunjava dva cilja. Prvo, omogućuje bolju ocjenu djelovanja uprave, a drugo, iz konkretne i neposredne perspektive, ostvarivanje prava na pristup dokumentima pruža mogućnost građaninu da izrazi

34 Idot, L., La transparence dans les procédures administratives, LGDJ, Paris, str. 121. 
svoje mišljenje ili istakne svoje argumente pri izradi ili protiv nacrta odluke ili djelovanja. ${ }^{35}$

Transparentnost se pokazala kao središnji stup demokratizacije djelovanja uprave, time što pridonosi legitimaciji europskog integracijskog procesa. Zaključci nezavisnog odvjetnika Poiaresa Madura, koje je iznio u presudi Kraljevina Švedska protiv Komisije, bili su prilika ne samo da se istakne put priznanja temeljne značajke prava na pristup dokumentima, već i da se podsjeti da je „to jačanje statusa prava na pristup usko povezano s promjenom ciljeva koji se žele ostvariti kroz 'imperativ transparentnosti'. Rijetke su obveze koje se ovako ili onako odnose na navedeni imperativ, a koje idu na teret institucija koje su od samog početka prvenstveno težile tome da osiguraju učinkovitost djelovanja Unije i kontrolu zakonitosti njezina djelovanja. (...) Nastupanjem prava na pristup dokumentima tijela javne vlasti, transparentnost teži jačanju demokratskog legitimiteta djelovanja Unije. “36 Nezavisni odvjetnik također naglašava opseg transparentnosti kao izvora legitimacije europskih integracija. No, ovaj demokratski koncept supostoji s instrumentalnim konceptom. Naime, ako su pojedincima priznata prava, to je prije svega u smislu u kojem se osigurava učinkovitost djelovanja Unije.

\subsubsection{Provedba prava na pristup dokumentima}

Uvođenje članka 255. Ugovora iz Amsterdama predstavljalo je pravni temelj za usvajanje sekundarnog zakonodavstva o primjeni prava na pristup dokumentima. Uredba (EZ) br. 1049/2001 usvojena je 30. svibnja 2001., a podsjeća na temeljnu značajku prava na pristup dokumentima što podrazumijeva da predstavlja predmet što je moguće šireg priznanja. Posljedično, svi dokumenti, u bilo kojem obliku, obuhvaćeni su njezinim područjem primjene.

$\mathrm{K}$ tome, nositelji prava na pristup dokumentima definirani su u širem smislu. Radi se o svakom građaninu ili o svakoj fizičkoj ili pravnoj osobi s boravištem ili registriranim sjedištem u državi članici. Korist od prava na pristup temelji se na dva alternativna kriterija, na državljanstvu i boravištu, a potonje omogućuje da se uzme u obzir poseban slučaj pravnih osoba. Osim toga, nije potrebno donijeti dokaz o interesu koji bi opravdao dobivanje dokumenta. Konačno, Uredba se primjenjuje samo na Vijeće, Europski parlament i Komisiju. Odgovarajući na poziv same Uredbe, agencije i ostala tijela Unije postupno su zadobili sličnu ili čak identičnu uredbu.

Opseg prava na pristup dokumentima uvelike je uvjetovan definiranjem iznimki koje može imati. One se odnose na zaštitu javnog interesa ili „na zaštitu privatnosti i integriteta pojedinca“. Zbog priznanja temeljne značajke prava na pristup, sve iznimke trebaju predstavljati strogo i razmjerno tumačenje u skladu s ciljem koji se želi postići. U presudi Verein für Konsumenteninformation, ${ }^{37}$ Sud je naveo sustav

35 Chevallier, J., op. cit. str. 444.

36 Sud Europske unije, 18. srpnja 2007., Royaume de Suede/Commission.

37 Opći sud Europske unije, 13. travnja 2005., Verein für Konsumenteninformation/Commission. 
ispitivanja očigledno pretjeranih zahtjeva. Institucija je dužna dokazati prekomjerno radno opterećenje, kao i pružiti dokaz da je uzela u obzir interes podnositelja zahtjeva za dobivanje dokumenata. U skladu s primjenom načela razmjernosti, Sud zahtijeva, kada je to moguće, omogućavanje djelomičnog pristupa traženom dokumentu. Također, kada su dokumenti povjerljivi, sudac zahtijeva da institucija odgovori na zahtjev podnositelja tako što će zacrniti odlomke koji sadržavaju zaštićene podatke. Institucija također treba izabrati rješenje koje je najpovoljnije za podnositelje zahtjeva. ${ }^{38}$ Sudska praksa koja se odnosi na pristup dokumentima također pokazuje da se zahtijeva ravnoteža između jamstva temeljnog prava koje se priznaje pojedincu i dobrog djelovanja upravnih službi, ${ }^{39}$ što se također odnosi na promicanje dobre uprave. Naime, ako „uzimanje u obzir radnog opterećenja izazvanog ostvarenjem prava na pristup i interesa podnositelja zahtjeva, u načelu, nije relevantno za usklađivanje opsega navedenog prava“, ${ }^{40}$ jamstvo koje se pruža građaninu ne može dovesti do „beskorisnog otežavanja radnog opterećenja institucije“ “. ${ }^{41}$ Upravo će na taj način biti zajamčeni „,interesi dobre uprave“, posebice kada Vijeće usklađuje interes za dobivanje dokumenata u fragmentarnom obliku i izazvanog radnog opterećenja. ${ }^{42}$ Prema engleskoj inačici presude, sudac radi razliku između interesa dobre uprave i načela sound administration, pri čemu prvi služi instituciji, a drugi podnositelju zahtjeva. Originalnost ovog rješenja temelji se na pozivu koji je Sud uputio da se uzme u obzir interes podnositelja zahtjeva, bez obzira na to što u ostatku postupka načelo predstavlja ravnodušnost u odnosu na interes podnositelja zahtjeva. ${ }^{43}$

\subsection{Promicanje upravnih postupovnih prava na temelju Aarhuške konvencije}

Područje okoliša, koje predstavlja zajedničku nadležnost Unije i država članica, posebno je pogodno za uzimanje u obzir zahtjeva pojedinaca pri usvajanju upravnih odluka. Ova promjena nastupila je pod utjecajem međunarodnog javnog prava, a posebice zbog Aarhuške konvencije o pristupu informacijama, sudjelovanju javnosti u postupku odlučivanja i pristupu pravosuđu u pitanju okoliša potpisanoj 25. lipnja 1998. Zajednica je odobrila Konvenciju odlukom Vijeća od 17. veljače 2005. Konvencija obvezuje institucije Unije i države članice od 17. svibnja 2005. Također su zajedničko potpisivanje i njezino potvrđivanje država članica i Zajednice, kao mješovitog sporazuma, istovremeno doveli do integriranja triju stupova Konvencije u zahtjeve Unije koji se primjenjuju na države članice: informiranje, sudjelovanje i pristup pravosuđu. Prva dva stupa Konvencije nalaze se u središtu

\footnotetext{
38 Opći sud Europske unije, 7. veljače 2002., Aldo Kuijer/Vijeće Europske unije.

39 Opći sud Europske unije, 19. srpnja 1999., Heidi Hautala/Vijeće.

40 Opći sud Europske unije, 13. travnja 2005., Verein fur Konsumentenininformation/Komisija.

41 Opći sud Europske unije, 15. ožujka 2006., BASF AG/Komisija.

42 Opći sud Europske unije, 19. srpnja 1999., Heidi Hautala/Vijeće.

43 Sud Europske unije, 1. veljače 2007., Jose Maria/Vijeće.
} 
promicanja vrijednosti koje podrazumijevaju upravnu demokraciju. Oni su doveli do istovremenog jačanja pristupa informacijama i prava na sudjelovanje u pitanjima okoliša u okviru europskog upravnog prostora. Treće, pristup pravosuđu potvrđuje važnost priznanja prava na tužbu kao element kontrole upravnog djelovanja.

\subsubsection{Promicanje pristupa informacijama u pitanju okoliša}

Pristup informacijama razlikuje se od pristupa dokumentima po svojoj općoj i nematerijalnoj dimenziji. Pristup je u središtu procesa transparentnosti koji omogućuje približavanje građana europskoj izgradnji. ${ }^{44}$ Pristup informacijama istovremeno je posljedica i preduvjet pristupa dokumentima. Prvi stup Aarhuške konvencije prvo je prenijela Direktiva 2003/4/EZ, koja je izmijenila Direktivu 90/313, o slobodi pristupa informacijama o okolišu. Direktiva postavlja zahtjeve koji se primjenjuju na kvalitetu pruženih informacija. Također, ona jača pravo na informacije pozivajući tijela javne vlasti da preuzmu ,aktivnu obvezu u pružanju informacija o okolišu“. ${ }^{45}$ Međutim, potvrđivanje Aarhuške konvencije nije nužno dovelo do revolucije u pravu Unije. Na primjer, članak 4. Konvencije preuzima Direktivu 90/113/EEZ u pogledu pasivnog pružanja informacija. Usprkos svemu, istina je da Konvencija pruža širu definiciju informacija o okolišu. Osim toga, Konvencija smanjuje raspoloživo vrijeme za pružanje informacije, načelno na mjesec dana, za razliku od dva mjeseca u Direktivi 90/313. U usporedbi s direktivom koja navodi samo obvezu aktivnog pružanja informacija o stanju okoliša, članak 5. Konvencije odnosi se na razvoj cjelokupnih sustava i kapaciteta potrebnih za prikupljanje relevantnih informacija o okolišu.

Direktiva 2003/4/EZ o pristupu javnosti informacijama o okolišu preuzela je ove elemente, što ,zasigurno predstavlja novi i zahtjevniji standard u pogledu pristupa informacijama o okolišu nego li ono što je predviđeno Konvencijom. Međutim, Direktiva se ne ograničava na provedbu obveza iz Konvencije u pravu Zajednice već, u određenim slučajevima, ide i malo dalje. “46 Direktiva obogaćuje definiciju o informacijama o okolišu i proširuje područje dostupnih informacija omogućujući pristup ne samo onim informacijama kojima raspolažu tijela vlasti, već i informacijama kojima raspolažu „za svoj vlastiti račun“, iako smisao razlikovanja nije do kraja razjašnjen. Interes tog sustava temelji se i na jasnoj definiciji iznimki u okviru kojih se informacije o emisijama u okoliš ne mogu smatrati povjerljivima.

Sudac Unije potvrdio je opseg prava na informacije o okolišu i pružio strogo tumačenje iznimki koje se mogu protiviti zahtjevima podnositelja zahtjeva. Sud je također podsjetio na izostanak dokaza o interesu koji treba predati kako bi se dobio

44 Moussis, N., „La construction européenne et le citoyen: déficit démocratique ou déficit d'information?", RMCUE, Paris, 2002., str. 153.

45 Delaunay, B., De la loi du 17. srpnja 1978 au droit à l'information en matière d'environnement, AJDA, Paris, str. 1316.

46 Jendroska, J., „Accès à la justice: remarques sur le statut juridique et le champ des obligations de la Convention d'Arhus dans le contexte de l'Union européenne“, RJE, Paris, 2009., str. 31. 
pristup informacijama o okolišu kojima raspolaže neko tijelo javne vlasti. Osim toga, iznimka koja se temelji na povjerljivosti treba se tumačiti u skladu s ciljem Aarhuške konvencije. Prema tome, opće načelo u njemačkom pravu, prema kojem upravni postupci tijela javne vlasti nisu javni, nije dovoljno za postavljanje temelja za jednu takvu iznimku koja se treba definirati posebnim pravilom. Sudac također nalaže tijelu javne vlasti da u svakom slučaju pristupi uravnoteženju interesa.

Jačanje prava na informacije o okolišu vodi postupnom usklađenju normi koje se nalažu europskoj i nacionalnim upravama. Naime, usvojena je Uredba (EZ) br. 1367/2006 o primjeni odredaba Aarhuške konvencije o pristupu informacijama u pitanju okoliša na institucije i tijela Zajednice. Sustav pristupa informacijama razlikuje se od pristupa dokumentima iako Uredba navodi da se „Uredba (EZ) br. 1049/2001 primjenjuje na sve zahtjeve za pristup informacijama o okolišu kojima raspolažu institucije ili tijela Zajednice“. Prema tome, njezino područje primjene šire je u odnosu na Uredbu (EZ) br. 1049/2001, a odnosi se na sve institucije i tijela Zajednice. Institucije su obvezne organizirati informacije o okolišu koje posjeduju, a posebice zahvaljujući uporabi novih tehnologija. K tome, člankom 5. nalaže im se zadovoljavanje standarda kvalitete samih informacija. Institucije i tijela Zajednice osiguravaju „u onoj mjeri u kojoj je to u njihovoj moći, da sve informacije koje sami sastavljaju odnosno koje se sastavljaju po njihovom nalogu budu ažurne, točne i usporedive. Ako podnositelj zahtjeva to zatraži, institucije i tijela Zajednice ga obavješćuju gdje može naći informacije o mjernim postupcima koji su korišteni kod sastavljanja informacija, uključujući metode analize, uzorkovanja i prethodne obrade uzoraka, ako su te informacije raspoložive. U protivnom ga mogu uputiti na standardizirani postupak koji je korišten." Jednako tako, efektivnost informacija zajamčena je kroz dostupnost i razumljivost informacija.

Kako razvoj pristupa informacijama doprinosi okončanju kulta tajnosti koji je nastao kao ,istinsko pravilo upravne deontologije“ ${ }^{47}$ tako i dalje postoji poteškoća koja se odnosi na kompleksifikaciju informacija. Na razini Europske unije, kao i u okviru država članica, informacije često izrađuju stručnjaci. Potrebno je uložiti napor u objašnjavanje građanima, a ne samo pružiti sirove informacije. K tome, koliko privlačan i uobičajen može biti koncept, transparentnost ipak ima određena ograničenja. Čak može imati i posljedice suprotne očekivanoj koristi i dovesti do određene artificijalizacije u djelovanju uprave. Kako se transparentnost ne bi iskrivila ili zaobišla, treba pratiti produbljivanje upravne demokracije, putem sudjelovanja pojedinaca u postupku odlučivanja. Sekundarno zakonodavstvo ostaje sektorsko i usko povezano s izazovima u pogledu zaštite okoliša, no može predstavljati temelj jedne kulture pristupa informacijama potičući širenje zajedničkih standarda. ${ }^{48}$

47 Chevallier, J., op. cit., str. 344.

48 Ibid. 
Dr. sc. Bosiljka Britvić Vetma i dr. sc. Marko Turudić: Uloga stranke u upravnom djelovanju... Zbornik radova Pravnog fakulteta u Splitu, god. 56, 1/2019., str. 157.- 177.

\subsubsection{Organizacija sudjelovanja u pitanju okoliša}

Pitanje sudjelovanja javnosti u postupku odlučivanja također je pobudilo interes kada su Aarhušku konvenciju potvrdili Zajednica i država članice. Sudjelovanje postaje korolar prava na informacije. Radi se o višeznačnom pojmu koji može označavati „način sudjelovanja u odlučivanju, u formiranju određenih tijela, u savjetodavnom postupku ili još sudjelovanje adresata kojem je upućena odluka u upravnom postupku ili konačno, političku ili sociološku pojavu nereguliranu zakonom, a izražava utjecaj kojeg određeni interesi mogu vršiti na oblikovanje i provedbu javnih politika i pravnih akata putem kojih se one ostvaruju“ “. ${ }^{49}$ Konvencija organizira sudjelovanje javnosti u postupku odlučivanja u pitanjima okoliša, a otišla je dalje od prava Unije koje je izgledalo kao referenca pri radu. Konvencija nalaže da potpisnici poštuju obvezu u pogledu sredstava tako što moraju voditi unutarnju upravnu politiku kojom se mijenjaju tradicionalna ponašanja državnih i javnih službenika koji trebaju napustiti tajnovitost u odnosu na javnost s ciljem njezinog jednostavnijeg sudjelovanja u postupku odlučivanja. Jasno se afirmira načelo priznanja, pa čak i podrške ,udrugama, organizacijama ili skupinama koje rade na promicanju ciljeva zaštite okoliša“". ${ }^{0}$

Ovaj stup Konvencije prenesen je u pravo Unije Direktivom 2003/35/EZ u onom dijelu koji se odnosi na države članice. Ovaj tekst predstavlja referentnu normu i postavlja načelo sudjelovanja javnosti u pitanjima okoliša. Prema tome, sudjelovanje se instrumentalizira kako bi se osigurala zaštita okoliša. Upravo zato sudjelovanje treba biti stvarno. Vođenje postupka strogo je određeno kako bi se javnosti pružila prilika da sudjeluje. Upravljanje vremenom je od velike važnosti, pa tako države članice trebaju predvidjeti razumne vremenske okvire za svaku fazu postupka. Osim toga, obrađeno je i pitanje troška. Ukoliko je plaćanje naknada moguće, ono treba biti razumno. ${ }^{51}$

Što se tiče europske uprave, uvjeti sudjelovanja uređeni su Uredbom (EZ) br. 1367/2006. Članak 9. određuje da se javnosti ,pravovremeno pruže mogućnosti sudjelovanja tijekom pripreme, izmjena i preispitivanja planova i programa koji se odnose na okoliš“. Javnost treba dobiti relevantne informacije. Uredba propisuje da je rok za dostavu primjedaba najmanje osam tjedana. I konačno, kako bi sudjelovanje bilo stvarno ,(...) institucije i tijela Zajednice vode računa o rezultatima sudjelovanja javnosti. Institucije i tijela Zajednice obavješćuju javnost o tom planu odnosno programu, uključujući njegov tekst, te o razlozima i razmatranjima na kojima se temelji odluka i navode podatke o sudjelovanju javnosti.“

Prednost mješovitog sporazuma temelji se na njegovoj sposobnosti napajanja nacionalnog pravnog poretka i poretka Unije. Širenje standarda sudjelovanja osigurano je u onoj mjeri u kojoj je organizirana provedba Aarhuške konvencije u državama članicama. Kada organizacija sudjelovanja u postupku odlučivanja u

49 Marcou, G., „L'administration entre contrôle parlementaire et participation des personnes privées. Un point de vue français“, $R U D H$, Paris, 2004., str. 354.

${ }^{50}$ Aarhuška konvencija, članak 3.

51 Sud Europske unije, 9. studenoga 2006., Komisija/Irska. 
pitanjima okoliša predstavlja inovativan element u promicanju upravne demokracije, tada obveza osiguravanja pristupa pravosuđu izgleda tradicionalnije. Nadalje, uvjeti koji se odnose na pitanja zaštite okoliša doveli su, usprkos svemu, do određenih poteškoća u prijenosu, pokazujući upravo korisnost postojanja međunarodne konvencije za dosljednu primjenu prava Unije kao izvora proceduralnih obveza.

\subsubsection{Pristup pravosuđu u pitanjima okoliša}

Članak 9., stavak 3. Aarhuške konvencije predviđa mogućnost pokretanja sudskih postupaka ili žalbenih postupaka kojima se osporavaju činjenja i nečinjenja privatnih osoba i tijela javne vlasti koji su u suprotnosti s pravom zaštite okoliša. U toj perspektivi, pristup pravosuđu sastavnica je upravne demokracije jer predstavlja sredstvo kontrole djelovanja tijela javne vlasti u pitanjima okoliša. Pristup pravosuđu obvezuje tijela vlasti na izvještavanje o svom djelovanju. Ako je pravo na tužbu priznato u pravnom poretku Unije i u nacionalnim pravnim porecima, tada je prijenos Aarhuške konvencije podrazumijevao određene preinake. Naime, kako bi pristup pravosuđu bio stvaran, neophodno je priznati tu mogućnost udrugama, a naročito nevladinim organizacijama. Najčešće je potrebno da su one i izričito osposobljene. Osim toga, Konvencija zahtijeva da domaća zakonodavstva priznaju interes pripadnicima zainteresirane javnosti.

Treći stup Aarhuške konvencije bio je predmet prijenosa u pravni poredak Unije putem Glave IV. Uredbe (EZ) br. 1367/2006. Istovremeno se organizira interno preispitivanje upravnih akata i postupci pred sudom čim neka institucija ili tijelo Unije usvoji akt. Članak 10. kaže da osposobljena nevladina organizacija ima pravo podnijeti zahtjev za prethodno preispitivanje u roku od šest tjedana od donošenja ili notifikacije akta. Institucija ili tijelo Unije treba odlučiti u roku od najviše osamnaest tjedana. Nevladina organizacija može zatim pokrenuti postupak pred Sudom EU-a kako bi osporila odluku ili suzdržanost uprave pri usvajanju odluke o preispitivanju. Nadalje, taj postupak valja obaviti sukladno relevantnim odredbama ugovora. To znači da Uredba ne uređuje posebni pravni lijek za osporavanja koja se odnose na pitanja okoliša. Sudski postupak podliježe uvjetima iz članka 263. (4) Ugovora o funkcioniranju Europske unije koji se često smatraju previše ograničavajućima. Naime, dokaz o interesu udruga često je složen. Prema tome, taj izbor izgleda nespojiv s jednim od ciljeva Aarhuške konvencije kojim se osigurava široki pristup pravosuđu s ciljem jačanja zaštite okoliša ${ }^{52}$ Ipak, nedavna sudska praksa Suda nastoji dokazati određeno ublažavanje u pogledu uvjeta prihvatljivosti čim se radi o pitanju primjene prava zaštite okoliša, a podnositelji zahtjeva oslanjaju se na članak 9. Konvencije.

Međutim, ovaj treći stup nije bio predmet centraliziranog prijenosa iz Europske unije u nacionalne pravne poretke. Naime, za razliku od pravila koja se odnose na pristup informacijama i na sudjelovanje, postupak usvajanja direktive o pristupu

52 Bétaille, J., „Accès à la justice de l'Union européenne, le Comité d'examen du respeect des dispositions de la Convention d'Aarhus s'immisce dans le dialogue des juges européens: à propos de la décision ACCC/C/2008/32 du 14 avril 2001“, RJE, Paris, 2001., str. 547. 
pravosuđu u pitanjima okoliša trenutno je zaustavljen. Postojeće razlike među nacionalnim pravnim porecima, a počesto i prekogranična dimenzija sporova o okolišu istovremeno su opravdavali djelovanje na razini Unije, s obzirom na primjenu načela supsidijarnosti. Ovaj prijedlog imao je za cilj određivanje minimalnih zahtjeva o pristupu upravnim i sudskim postupcima u pitanjima okoliša. Prijedlog članka 10. kaže da „države članice će predvidjeti odgovarajuće i učinkovite postupke koji su objektivni, pravedni i brzi, a ne preskupi“. Prema tome, usklađenje upravnosudskih postupaka vrlo je ograničeno zbog načela o postupovnoj autonomiji. Nadalje, osjetljivost teme nije omogućila institucijama Unije omogućiti razvoj tog procesa. Također, pristup pravosuđu u pitanjima okoliša zajamčen je samo kada je povezan s pristupom informacijama ili s pravom na sudjelovanje.

Usprkos svemu, istina je da Sud Europske unije nastoji što više uokviriti postupovnu autonomiju država, a posebice s ciljem osiguravanja što je moguće šireg pristupa sucu u korist udruga. ${ }^{53}$ Također, u presudi Lesoochranárske zoskupenie $V L K$ od 8. ožujka 2011., Sud odbija priznati izravni učinak članka 9., stavka 3. Aarhuške konvencije, u onoj mjeri u kojoj on ne ispunjava klasične uvjete tog priznanja. Međutim, Sud je nadležan za tumačenje odredbe iz Konvencije jer je Aarhuška konvencija sastavni dio pravnog poretka Unije i podsjeća da države članice imaju obvezu osigurati stvarnu upravnosudsku zaštitu u područjima koje pokriva pravo zaštite okoliša Unije. Na temelju načela stvarnosti i istovrijednosti, nacionalni sudac treba omogućiti udruzi podnositelju zahtjeva da ospori odluku donesenu nakon okončanja postupka koja je suprotna pravu zaštite okoliša pred sudom. Prema tome, sudac Europske unije, u određenoj mjeri, izgleda kao jamac minimalnih postupovnih standarda, pa čak i ako djelovanje Unije ostaje u pozadini.

\section{ZAŠTITA POJEDINCA KROZ PRIZMU EFIKASNOG IZVRŠENJA ODLUKA}

Izvršenje upravnosudskih odluka jedno je od ključnih pitanja koje je snažno povezano sa zaštitom prava stranke u djelovanju javnopravnih tijela. Tako članak 13. Europske konvencije za zaštitu ljudskih prava govori o pravu na djelotvorni pravni lijek pred „domaćim javnopravnim tijelima“ koje ne mora biti sudsko tijelo. Izvršenje upravnosudskih odluka smatra se sastavnim dijelom suđenja, a neizvršenje presuda u razumnom roku posebno se kvalificira kao povreda „prava na sud“ iz članka 6. stavka 1. Europske konvencije za zaštitu ljudskih prava.

Dovršetak normizacije prava na djelotvorni pravni lijek i ,potvrđivanje autonomnosti prava na djelotvorni pravni lijek“ uglavnom su rezultat presude Kudla protiv Poljske od 26. listopada 2000. ${ }^{54} \mathrm{U}$ spomenutoj presudi Sud prihvaća ispitati pritužbu proizašlu iz povrede članka 13. zato što nije predviđeno pravno

53 Sud Europske unije, 15. listopada 2009., Djurgarden-Lilla Vartans Miljoskyddsforening/ Stockholms kommun genom dess marknamnd.

54 Europski sud za zaštitu ljudskih prava, 26. listopada 2000., Kudla protiv Poljske. 
sredstvo koje omogućuje podnositelju zahtjeva da potvrdi svoje pravo na suđenje u razumnom roku.

Od prevelike je važnosti da istinsko pravo na djelotvorni pravni lijek bude na raspolaganju strankama, dok opseg toga prava treba precizirati.

Prvo, „djelotvornost pravnih sredstava“ u smislu članka 13., naravno, ne ovisi o izvjesnosti povoljnog ishoda za podnositelja zahtjeva. Također, „,državno tijelo“ iz ove odredbe ne treba biti sudsko tijelo, ali njegove ovlasti i jamstva koja predstavlja uzimaju se u obzir pri ocjeni djelotvornosti pravnog lijeka koje se ulaže pred tim tijelom..$^{55}$ Nadalje, svi pravni lijekovi dostupni u nacionalnom pravu mogu ispuniti zahtjeve iz članka 13. iako ih nijedan od njih samostalno ne ispunjava. ${ }^{56}$

Zatim, pravni lijek iz članka 13. ,treba biti djelotvoran de facto i de iure“.57 Prema tome, Sud nalaže državama pozitivnu obvezu opskrbljivanja internim pravnim lijekovima. ${ }^{58}$ Nadalje, država se obvezuje kroz pozitivnu obvezu donijeti „odgovarajuće i dostatne mjere“ kako bi se osiguralo izvršenje sudske odluke, ${ }^{59}$ uključujući i izvršenje u okviru privatnih sporova. ${ }^{60}$

Europski je sud za ljudska prava u predmetima Zazanis i drugi protiv Grčke i Fotopoulou protiv Grčke podsjetio da se pravni lijek ne može smatrati djelotvornim u smislu članka 13. jer je uprava odbila ili zanemarila izvršiti presudu koju su donijeli nacionalni sudovi.

Jedan od predmeta, tj. predmet Zazanis, zaslužuje podrobniji prikaz. ${ }^{61}$ Podnositelji zahtjeva bili su grčki državljani, vlasnici zemljišta uključenog u plan grada kao građevinsko zemljište 70-ih godina prošlog stoljeća, ali je u općinski katastar to zemljište upisano kao sastavni dio šumskog područja 80-ih godina. Oni su s građevinskim poduzećem potpisali ugovor koji je predviđao izgradnju višekatnice na svom zemljištu 90-ih godina. To je poduzeće ishodilo građevinsku dozvolu, koju je, međutim, grčki Državni savjet poništio zbog toga što poduzeće prethodno nije ishodilo dozvolu za sječu stabala koja su se nalazila na tom zemljištu. Poduzeće je bezuspješno predavalo zahtjeve za sječu prije nego što je podnijelo žalbu Državnom savjetu koji je, u odluci iz 2000., prihvatio žalbu i smatrao da su svi dokumenti predani i vratio predmet javnopravnom tijelu kako bi ono donijelo odluku o zahtjevu za sječom stabala. Usprkos ovoj odluci, općina je uporno zahtijevala od poduzeća da ispuni uvjete koji nisu predviđeni zakonom i smanjila je za polovicu površinu građevinskog zemljišta. Zatim je ministar za zaštitu okoliša donio dekret o izmjeni korištenja spornog zemljišta u ,zelenu površinu“. Podnositelji zahtjeva su na temelju

55 Europski sud za zaštitu ljudskih prava, 27. ožujka 2003., Dactylidi protiv Grčke.

56 Europski sud za zaštitu ljudskih prava, 25. ožujka 1983., Silver $i$ drugi protiv Ujedinjenog Kraljevstva; Europski sud za zaštitu ljudskih prava, 15. studenoga 1996., Chahal protiv Ujedinjenog Kraljevstva.

57 Europski sud za zaštitu ljudskih prava, 27. lipnja 2000., Ihlan protiv Turske.

58 Vidi, Preporuku (2003.) 17 Vijeća Europe.

59 Europski sud za zaštitu ljudskih prava, 17. lipnja 2003., Ruianu protiv Rumunije.

60 Europski sud za zaštitu ljudskih prava, 22. lipnja 2004., Pini i Bertani protiv Rumunije.

61 Navodi Europskog suda za zaštitu ljudskih prava. 
članka 6. stavak 1. i članka 13. Konvencije prijavili odbijanje javnopravnog tijela da se uskladi s presudom Državnog savjeta od 17. kolovoza 2000. kojom je poništena odluka o odbijanju dodjele urbanističke dozvole. Nakon preispitivanja okolnosti u ovom slučaju, Sud je smatrao da je ravnateljstvo za urbanizam odredilo nove uvjete koji su izjednačeni s neispunjavanjem presude Državnog savjeta. Nadalje, Sud je utvrdio da je odluka ministra za zaštitu okoliša, koji je prekvalificirao sporno zemljište u ,zelenu površinu“, tri godine nakon presude Državnog savjeta, izjednačena s formalnim nalogom za izvlaštenje koji lišava presudu njezine biti. Prema tome, Sud je zaključio da je nastupila povreda članka 6. stavka 1. kao i članka 13. zbog nedostatka pravnog lijeka u nacionalnom pravu koji bi omogućio podnositeljima zahtjeva da postignu izvršenje presude Državnog savjeta. Od prevelike je važnosti da istinsko pravo na djelotvorni pravni lijek bude na raspolaganju strankama, dok opseg tog prava ne treba precizirati. Neizvršenje presude predstavlja kršenje članka 6. stavka 1., bilo da je rezultat neprisutnosti uprave, sudskog službenika ili same države. Izvršenje treba biti potpuno, savršeno, a ne djelomično, a naknada zbog teške pogreške države, zbog toga što je odbila pružiti pomoć pri izvršenju sporne odluke, također ne može nadoknaditi nedostatak u izvršenju presude.

Od prevelike je važnosti da istinsko pravo na djelotvorni pravni lijek bude na raspolaganju strankama, dok opseg toga prava treba precizirati. ${ }^{62}$

\section{ZAKLJUČAK}

Promicanje dobre uprave pridonijelo je jačanju položaja koje pojedinac ima u okviru upravnog procesa. Naime, pojam potiče na egalitarnije iščitavanje upravnih odnosa. Jednako tako, uzimanje u obzir interesa građanina treba predstavljati bitni dio upravne odluke. Ipak, izgleda da dobra uprava ne može postaviti temelje za inovativan status pojedinca. Iako članak 41. Povelje Europske unije o temeljnim pravima nastoji istaknuti poveznicu između prava na dobru upravu i građanstva, njezin stvarni doprinos izgradnji upravne demokracije teško nadilazi formalnu fazu.

Pozivanje na dobru upravu ovdje pokazuje koja su njezina ograničenja. Naime, ako je dobra uprava omogućila jačanje pojedinačnog statusa građanina, u konkretnom smislu, ona ipak ne postavlja temelje za stvarno priznanje postupovnih prava u kolektivnom smislu. Ako je potvrđeno pravo na saslušanje u okviru pojedinačnog upravnog postupka, tako se pravo na sudjelovanje, koje također nastupa prije usvajanja odluke, razmatra na vrlo ograničen način. Ograničeni doprinos načela dobre uprave u postupku demokratizacije uprave objašnjava se činjenicom da se njime prvo nastoji osigurati učinkovito funkcioniranje uprave. Upravo je zato uključivanje pojedinaca organizirano u bitno instrumentalnoj perspektivi; uključeni su samo u onoj mjeri u kojoj mogu doprinijeti učinkovitosti izvršnosti u upravnim pitanjima.

62 Više o svemu vidi u Britvić Vetma, B., „Utjecaj konvencijskog prava i prava Europske unije na zaštitu prava stranke u upravnom sporu“, Zbornik Pravnog fakulteta Sveučilišta u Rijeci, Vol. 37, 01/16., Rijeka, 2016., str. 291-315. 
Prema tome, razvoj pojma dobre uprave ovisi o njezinu artikuliranju i o njezinu obogaćivanju referiranjem na druge temelje produbljivanja upravnih odnosa. Nesporno je da prijenos Aarhuške konvencije u područje prava Unije predstavlja zanimljiv temelj za promicanje načela upravne demokracije u području zaštite okoliša. Čitanje u kombinaciji s dobrom upravom moglo bi biti zanimljiv put za općenito priznanje pojedinačnih prerogativa u upravnom procesu i njihov razvoj u europskom upravnom prostoru.

\section{THE ROLE OF PARTY IN THE ADMINISTRATIVE ACTIVITY OF LEGAL PUBLIC BODIES}

The authors in this article consider the role and with it the position of party in the administrative activity of legal public bodies. Particular emphasis is placed on the principle of good administration. It is pointed out that promoting good administration is closely linked to democratization of administration which is directed at advocating development which goes from citizens being subjugated to administration to citizens being equal with administration. To this aim, authors also consider the influence of European Law on the protection of the rights of citizen as a party.

Key words: customer, protection of rights, good administration 